\title{
A CSIGAMARÓ SZÁRMAZTATÓ FELÜLETÉNEK TORZULÁSA AZ UTÁNÉLEZÉSEKKEL
}

\section{THE DEFORMATON OF THE GEAR HOB'S GENERATING SURFACES DUE TO THE RE-SHARPENING}

\author{
Máté Márton ${ }^{1}$, Hollanda Dénes ${ }^{2}$ \\ ${ }^{1}$ Sapientia Erdélyi Magyar Tudományegyetem, Marosvásárhelyi Kar, Gépészmérnö- \\ ki Tanszék, 540485 Marosvásárhely, O.p.9, C.P 4, Telefon / Fax: +40-265-206210 / \\ +40-265-206211,mmate@ms.sapientia.ro \\ ${ }^{2}$ Sapientia Erdélyi Magyar Tudományegyetem, Marosvásárhelyi Kar, Gépészmérnö- \\ ki Tanszék, 540485 Marosvásárhely, O.p.9, C.P 4, Telefon / Fax: +40-265-206210 / \\ +40-265-206211, hollanda@ms.sapientia.ro
}

\begin{abstract}
The side relief faces of the monolithic involute gear hob are machined through relieving. The resulting surfaces are bevel helical surfaces where the side cutting edges result by intersecting these with the helical rake face. Theoretically the gear hob is derived from an involute worm. The re-sharpening decreases the diameters of the hob, thus the edges became closer to the axis, and as a consequence they will be situated on a smaller worm than the original. The present paper analyses the deviation of the re-sharpened gear hob's carrying worm from the theoretically perfect involute worm whose characteristic dimensions were adjusted considering the re-sharpened gear hob' characteristic diameters. It was proven that the evolution of the errors is firmly different from that described in the literature. Thus it is unnecessary the increasing of the new gear hob diameters in comparison with the calculated dimensions while the error cannot be reduced to half with this procedure. The mathematical model was built up accepting that the edges result as the intersection of an involute worm with a helical rake face and the side relief faces result by the rototranslation of the edges on a bevel helix leading curve dressed by the relieving parameter.
\end{abstract}

Keywords: gear-hob, involute worm, relieving, re-sharpening, error.

\section{Összefoglalás}

A monolit felépítésủ csigamaró fogainak oldal-hátfelületét hátramunkálással hozzák létre. Ezek kúpos csavarfelületek, melyeken a csavar-homlokfelülettel való metszés következtében keletkeznek a burkolásban részt vevő oldalélek. Elméletileg a csigamarót evolvens csigából származtatják. Az utánélezések során az élek egyre közelebb kerülnek a tengelyhez, így egyre kisebb csigán illeszkednek, mint az új csigamaró élei. Ezek a csigák viszont már nem kongruensek az eredeti származtató evolvens csigával. Jelen dolgozat az utánélezett csigamaró származtató csigájának eltérését tanulmányozza attól az elméletileg tökéletes evolvens csigától, melynek karakterisztikus átmérőit az utánélezett csigamaróhoz igazítottuk. Kimutattuk ezáltal, hogy a szakirodalomból ismert állásponttól különböző a torzulás és az utánélezési állapot közötti összefüggés. A csigamarót fölösleges megnövelni a tervezetthez viszonyított mérethez képest, mert ez nem vezet a hibák felezéséhez. A matematikai modell feltétele, hogy a csigamaró élei az evolvens csiga oldalfelületeinek és a csavar-homlokfelületnek a metszésvonalai, a hátfelület pedig az előbb említett metszésvonalak kúpos csavarvonalon való elmozdításával jönnek létre.

Kulcsszavak: csigamaró, evolvens csiga, hátramunkálás, újraélezés, hiba. 


\section{A csigamaró származtató csigá- jának modellje}

Az evolvens hengeres fogaskerék lefejtő csigamarójának származtató csigáját jelen tanulmányban evolvens csigának tekintjük, a szakirodalom túlnyomó részében elfogadott nézettel egyetértésben [1...8]. Az evolvens csiga generálását matematikai szempontból kétféleképpen írhatjuk le [1, 3, $4,5,6,8]$ : a generáló egyenesek, vagy pedig a homlokszelvénybeli evolvensek csavarvonalon történő elmozdításával. Jelen modellben az alkotó egyeneseket használjuk fel, de ezeket, az egyenletek minél nagyobb fokú egyszerüsítése miatt, sajátos helyzetből indítjuk, mely különbözik a gyártástechnológiában használatos helyzettől $[1,3,4,5]$. Az evolvens csiga alaphengerére illesztett evolvensgörbék és a megfelelő generáló egyenesek az 1. ábrán láthatók. A csigamaró $z$ forgástengelyének balróljobbra való irányításának megfelelően, a $C A_{1}$ evolvens-ívet leképező $A_{1} A_{2}$ egyenes a jobb oldali, míg a $D B_{1}$ evolvens-ívhez tartozó $B_{1} B_{2}$ egyenes a bal oldali csavarfelületet fogja generálni. A jobb, illetve baloldal meghatározást a csiga fogára értelmeztük. Az egyenesek $\lambda_{b}$ dölésszöge az alaphengeri csavarvonal dőlésszögével megegyező. Az $\alpha_{o t}$ kapcsolószöget a $\lambda_{0}$ osztóhengeri vezércsavarvonal dőlésszögéből, az $m_{n}$ normálmodul-értékből és a csiga bekezdéseinek $i$ számából számoljuk, az evolvensgeometria segítségével [9]. Jelen tanulmányban egyetlen bekezdésü csigát tekintünk.

A csigához csatolt xyz koordinátarendszert úgy választjuk meg, hogy az $y$ tengely a homlokszelvény szimmetriatengelye legyen. A generáló egyeneseket elméletileg bármilyen helyzetbe el lehet csavarni az 1. ábrán feltüntetett helyzethez viszonyítva, azzal a feltétellel, hogy az alaphengeri pontjaik az alaphengeri csavarvonalakat kövessék.

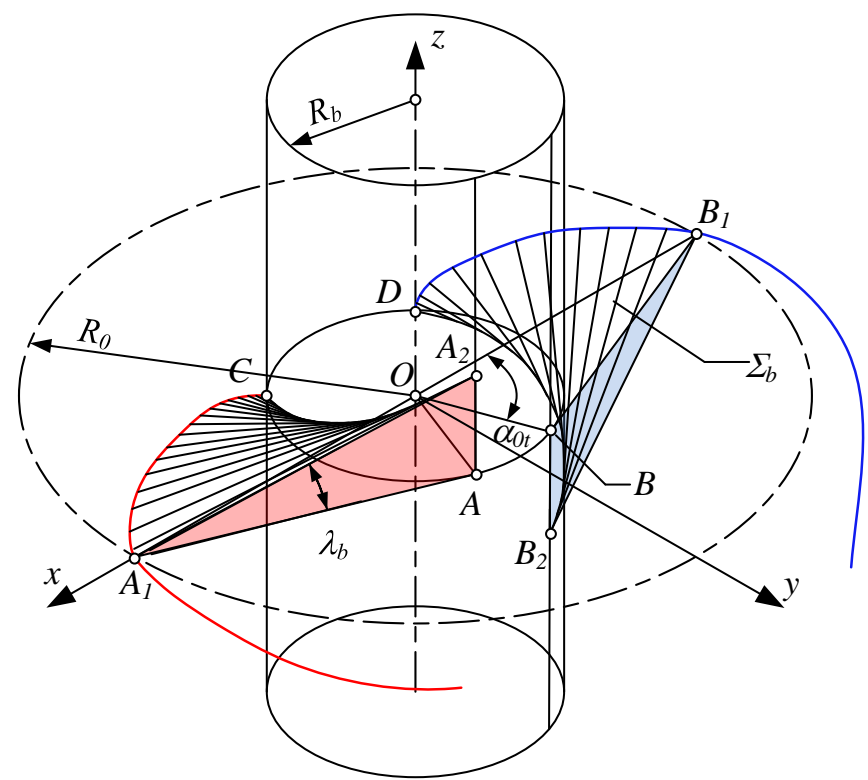

1. ábra. Az evolvens csiga tengelyszelvényére illesztett generáló egyenesek. 


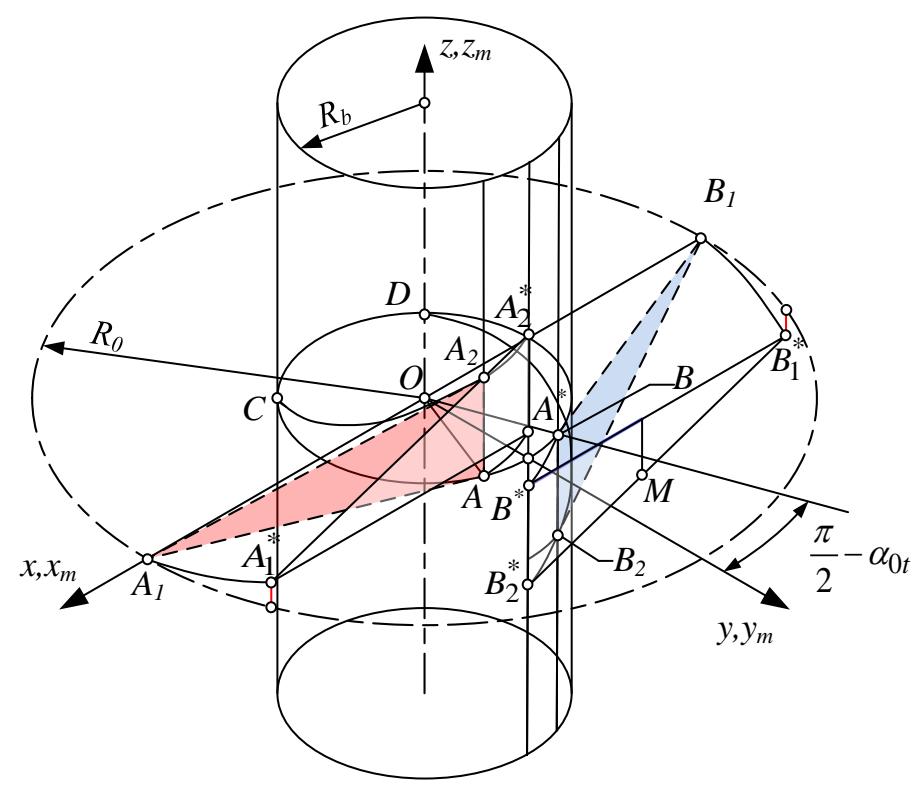

2. ábra. Az evolvens csiga generáló egyenesei elforgatása az alaphelyzetbe.

Ezt a tulajdonságot kihasználva, a számítás lényegesen egyszerüsödik, ha az alaphengereket érintő, a generáló egyeneseket tartalmazó $\left(A A_{1} A_{2}\right)$ illetve $\left(B B_{1} B_{2}\right)$ síkokat egymással párhuzamos, és az $y$ tengelyre merőleges helyzetbe csavarjuk el. Ezáltal az $A_{1} A_{2}$ egyenes az $A_{1}^{*} A_{2}^{*}$, a $B_{1} B_{2}$ pedig a $B_{1}^{*} B_{2}^{*}$ helyzetbe kerül. Az elcsavarás paraméterei a $p_{a x}=\frac{\pi m_{n}}{\cos \lambda_{0}}$ menetemelkedés, illetve a $\frac{\pi}{2}-\alpha_{0 t}$ elforgatási szög.

A 2. ábra alapján, egyszerüen felírhatók az alkotó egyenesek egyenletei:

$$
\left\{\begin{array}{l}
x(u)=R_{b} \\
y(u)=-j u \\
z(u)=j\left(h_{b}-u \operatorname{tg} l_{b}\right) \quad, j \in\{-1 ; 1\} \\
h_{b}=\frac{m_{n}}{2 \cos \lambda_{0}}\left(\frac{\pi}{2}+\operatorname{inv} \alpha_{0 t}\right)
\end{array}\right.
$$

Az (1) képletben szereplő $j$ paraméter -1 értéke a bal, +1 pedig a jobb oldalra vonatkozik.

A csiga fogfelületeit a [8]-ban leírt módon kapjuk azáltal, hogy az éleket a mozgó $x_{m} y_{m} z_{m}$ koordináta-rendszerhez csatoljuk, majd ezt az álló $x y z$ rendszerhez képest a csiga paramétereinek megfelelően csavarjuk el. Célszerü az elforgatás $v$ paraméterét pozitív értékeken tartani, így a transzformáció mátrixa a következő lesz:

$$
\mathbf{M}(v ; j)=\left(\begin{array}{cccc}
\cos j v & -\sin j v & 0 & 0 \\
\sin j v & \cos j v & 0 & 0 \\
0 & 0 & 1 & \frac{p_{a x}}{2 \pi} v \\
0 & 0 & 0 & 1
\end{array}\right)
$$

Az (1) és (2) felhasználásával a származtató csiga felületeinek egyenleteit a [3,4] -ben felírt mátrixegyenletből kapjuk: 


$$
\left\{\begin{array}{l}
x(u, v)=R_{b} \cos v+u \sin v \\
y(u, v)=j\left(R_{b} \sin v-u \cos v\right) \\
z(u, v)=j\left(h_{b}-u \operatorname{tg} \lambda_{b}+\frac{p_{a z}}{2 \pi} v\right)
\end{array}\right.
$$

A z koordináta kifejezésében szereplő $h_{b}$ paraméter az $A_{2}^{*}$ és $B_{2}^{*}$ pontok $(x y)$ síktól mért távolságát jelenti (2. ábra). Értékét a következő képlettel számoljuk:

$$
h_{b}=\frac{m_{n}}{2 \cos \lambda_{0}}\left(\frac{\pi}{2}+\operatorname{inv} \alpha_{0 t}\right)
$$

Megfigyelhetö a (3) egyenletekben az $u$ és a $v$ paraméterek elválasztása, ami igen elönyös a homlokfelülettel való elmetszés számításakor.

\section{Az evolvens csigamaró oldal- hátfelületei}

\subsection{A hátfelület-generáló élek}

A hátfelület-generáló élek a tervezett evolvens csiga és a homlokfelület metszésvonalai. A homlokfelület a csigával ellentétes irányú csavarfelület, melynek osztóhengeri csavarvonala meröleges a csiga osztóhengeri csavarvonalára, tehát érintője a $z$ tengellyel a $\lambda_{0}$ szöget zárja. A parametrikus egyenletek felírásakor feltételezzük, hogy a generáló egyenes, alaphelyzetben az $x$ tengellyel $-\varepsilon$ szöget zárja. Ezzel általánosítjuk a homlokfelület helyzetét a csigamaró fogához viszonyítva. Az $\varepsilon=0$ érték a homlokfelület alaphelyzetét adja. A 3. ábra alapján, a homlokfelület parametrikus egyenletei a következők:

$$
\left\{\begin{array}{l}
x(t, w ; \varepsilon)=t \cos (w-\varepsilon) \\
y(t, w ; \varepsilon)=t \sin (w-\varepsilon) \\
z(t, w ; \varepsilon)=-\frac{p_{C}}{2 \pi} w
\end{array}\right.
$$

A $p_{C}$ homlokfelület- csavaremelkedést a vezérvonalak merőlegességéből számítják ki [8].

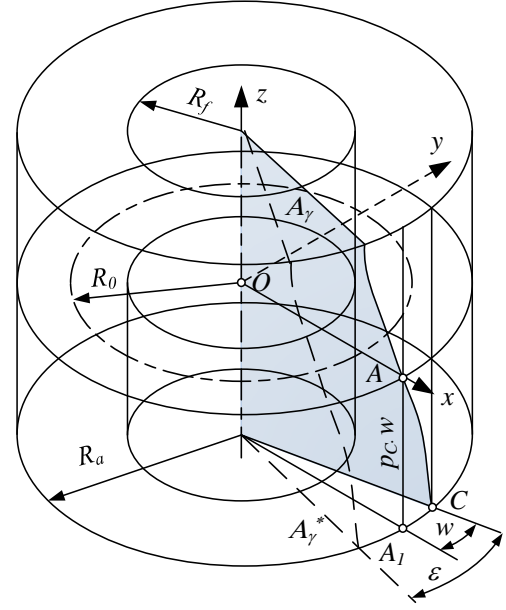

3. ábra. A csigamaró homlokfelülete

Az elkövetkező számításokban ennek implicit alakját használjuk:

$$
\operatorname{arctg} \frac{y}{x}+\frac{2 \pi}{p_{C}} z+\varepsilon=0
$$

A hátfelület-generáló élek, a csigamaró elméleti vagy tervezési élei, a homlokfelület és a csiga felületeinek metszésvonalai. A (3) és (6) egyenletek együttes vizsgálatából, $\varepsilon=0$-ra kapjuk a keresett éleket meghatározó, $u$ és $v$ paraméterek közötti kapcsolatot:

$$
\begin{array}{r}
v(u)=\frac{p_{C}}{p_{a x}+p_{C}}\left(\operatorname{arctg} \frac{u}{R_{b}}-j \varepsilon\right)+ \\
+\frac{2 \pi}{p_{a x}+p_{C}}\left(u \operatorname{tg} \lambda_{b}-h_{b}\right)
\end{array}
$$

Az élek parametrikus egyenleteit a (3) képletek adják, ha a $v$ paramétert a (7) függvénnyel helyettesítjük.

\subsection{Az oldalhátfelületek egyenletei}

$\mathrm{Az}$ oldalhátfelületeket úgy generáljuk, hogy az elméleti éleket a hátramunkálás $k$ paraméterének és a menetemelkedés $p_{a x}$ értékének megfelelö kúpos csavarvonalon mozdítjuk el. A generálás geometriai mo- 
dellje részletesen megtalálható a [3,4,8] publikációkban. A [8]-ban megadott koordináta-transzformáció alkalmazásával, a parametrikus hátfelület-egyenletek a következők lesznek:

$$
\left\{\begin{aligned}
& x(u, \varphi ; j)= R_{b} \cos E(u, \varphi)+u \sin E(u, \varphi)- \\
&-a \varphi \cos \varphi \\
& y(u, \varphi ; j)= j\left(R_{b} \sin E(u, \varphi)-u \cos E(u, \varphi)\right)+ \\
&+a \varphi \sin \varphi \\
& z(u, \varphi ; j)= j\left(h_{b}-u \operatorname{tg} \lambda_{b}+\frac{p_{a x}}{2 \pi} E(u, \varphi)\right) \\
& E(u, \varphi)=v(u)-j \varphi
\end{aligned}\right.
$$

\section{Az utánélezett csigamaró burko- ló csigája}

Ha az elméleti éleket egy $p_{a x}$ emelkedésű vezércsavarvonalon elmozdítjuk, ezek visszagenerálják azt az evolvens csigát, amelyből származnak. A csigamaró utánélezése a homlokfelület $z$ tengely körüli, $\varepsilon$ szöggel történő elfordításának felel meg, így az új élek $\delta_{\varepsilon}=\frac{k z_{m}}{2 \pi} \varepsilon$ értékkel közelednek a csigamaró tengelyéhez, és ennek következtében ezek már egy $2 \delta_{\varepsilon}$ értékkel csökkentett átmérőjü csigára illeszkednek. A csökkentett osztókör-átmérő az állandó $p_{a x}$ emelkedés mellett nagyobb dőlésszögü csigát határoz meg.

Az új élek burkoló csigájának kiszámításához a (8) hátfelület-egyenleteket a (6) homlokfelület-egyenletbe helyettesítjük. Implicit egyenletet kapunk, $u, \varphi$ ismeretlenekben, amely a következő alakra hozható:

$$
\begin{aligned}
& \varphi+j \xi(u, \varphi)- \\
& -j \frac{2 \pi\left(h_{b}-u \operatorname{tg} \lambda_{b}\right)+p_{a x}(v(u)-j \varphi)}{p_{C}}-\varepsilon=0
\end{aligned}
$$

A (9) egyenletben a következő függvények szerepelnek:

$$
\begin{aligned}
& E_{1}(u)=v(u)-\operatorname{arctg} \frac{u}{R_{b}} \\
& Q(u)=\frac{k z_{m}}{R_{b}} \varphi \cos \left(\operatorname{arctg} \frac{u}{R_{b}}\right)-\cos E_{1}(u) \\
& \xi(u, \varphi)=\operatorname{arctg} \frac{\sin E_{1}(u)}{Q(u)}
\end{aligned}
$$

Belátható, hogy a kapott egyenlet transzcendens $\varphi$-ben, következésképpen csak numerikusan oldható meg. A numerikus megoldást az $u$ paraméter $N$ diszkrét értékére végezzük el. Figyelembe véve a származtató evolvens csiga (3) parametrikus egyenleteit, az első kettőből következik, hogy a tetszőleges felületpont $z$ forgástengelytől való távolságát a

$$
\rho=\sqrt{R_{b}^{2}+u^{2}}
$$

összefüggés adja meg. A csiga felületét a lábhenger és a fejhenger között értelmezzük. Ez alapján a (11) felhasználásával kapjuk, hogy

$$
\sqrt{R_{f}^{2}-R_{b}^{2}} \leq u \leq \sqrt{R_{a}^{2}-R_{b}^{2}}
$$

$\mathrm{Az}\left\lfloor R_{f}, R_{a}\right\rfloor$ intervallumon egyenletes felosztást definiálunk:

$$
\begin{aligned}
& \rho_{l}=R_{f}+l \Delta_{\rho}, \Delta_{\rho}=\left(R_{a}-R_{f}\right) /(N-1), \\
& l=0,1, \ldots, N-1
\end{aligned}
$$

A (11) képlettel a (13) egyenletes sugárfelosztásnak megfelelő $u$ - felosztást képezünk. Az $N$ darab $u_{l}, l=\overline{0 . . N-1}$ értékre megoldjuk a (9) egyenletet, és ezáltal $\mathrm{N}$ darab $\left(u_{l}, \varphi_{l}\right), l=\overline{0 . . N-1}$ rendezett párt kapunk. Ezeket behelyettesítve a hátfelület (8) parametrikus egyenleteibe, $3 N$ darab koordinátát kapunk. Ezekre és az $u_{l}$ értékekre három köbös spline függvényt illesz- 
tünk, melyek segítségével az új éleket kizárólag az u függvényében írjuk fel:

$$
\left\{\begin{array}{l}
x(u)=S_{x}(u) \\
y(u)=S_{y}(u) \\
z(u)=S_{z}(u)
\end{array}\right.
$$

Az új éleket burkoló csiga felületei lesznek a fogaskerék származató felületei.
Ezeket a következő mátrixegyenletből kapjuk:

$\underline{\mathbf{r}}(u, w)=\left(\begin{array}{cccc}\cos w & -\sin w & 0 & 0 \\ \sin w & \cos w & 0 & 0 \\ 0 & 0 & 1 & \frac{p_{a x}}{2 \pi} w \\ 0 & 0 & 0 & 1\end{array}\right)\left(\begin{array}{c}S_{x}(u) \\ S_{y}(u) \\ S_{z}(u) \\ 1\end{array}\right)$

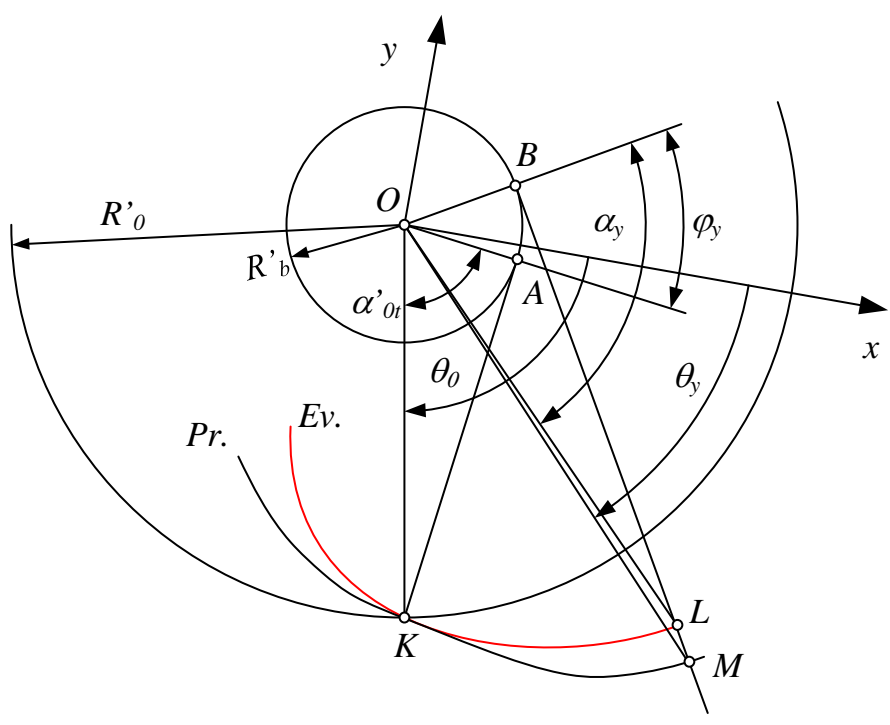

4. ábra. A származtatófelület-hiba definíciója

\section{Az utánélezett állapotnak meg- felelő ideális evolvens csiga}

Az utánélezés következében az osztókörsugár az

$$
R_{0}^{\prime}=R_{0}-\delta_{e}
$$

értékre csökken. A normálmodul értéke meg kell maradjon (elméletileg ez is változik [4]), így az osztóhengeri csavarvonal dőlésszöge

$$
\lambda_{0}^{\prime}=\arcsin \frac{\pi m_{n}}{2 \pi R_{0}^{\prime}}
$$

Ezek ismeretében ki lehet számítani az evolvens csiga további paramétereit:

$$
\begin{aligned}
& \alpha_{0 t}^{\prime}=\operatorname{arctg} \frac{\operatorname{tg} \alpha_{0 n}}{\sin \lambda_{0}^{\prime}} \\
& R_{b}^{\prime}=R_{0}^{\prime} \cos \alpha_{0 t}^{\prime}
\end{aligned}
$$

\section{A hiba számítása}

A származtató csiga hibáját az utánélezés során csökkent méretü osztóhenger-sugárra definiált tökéletes evolvens csiga és az új élek által burkolt csiga radiálszelvényei közötti különbségként definiáljuk. A definíció geometriai megfo- 
galmazását a 4. ábra szemlélteti. A hiba az ideális evolvens ív és a származtató csiga szelvénye közötti távolság, az osztóköri szelvényponton áthaladó evolvensre merölegesen mérve.

A burkoló csiga tengelyszelvényét a (15) egyenlet kifejtésével, és a z- koordináta nullává tételéből kapjuk:

$$
\begin{gathered}
z(u, w)=0 \Leftrightarrow S_{z}(u)+\frac{p_{a x}}{2 \pi} w=0 \\
w(u)=-\frac{2 \pi}{p_{a x}} S_{z}(u) \\
\left\{\begin{array}{l}
x(u)=S_{x}(u) \cos w(u)-S_{y}(u) \sin w(u) \\
y(u)=S_{x}(u) \sin w(u)+S_{y}(u) \cos w(u)
\end{array}\right.
\end{gathered}
$$

A (21 kifejezésekbe behelyettesítjük az u paraméter osztókörre vonatkozó értékét. Ezt a (21) koordináta-függvényekből származtatott

$$
\left(R_{0}^{\prime}\right)^{2}-S_{x}^{2}(u)-S_{y}^{2}(u)=0
$$

egyenletböl nyerjük, jelöljük gyökét $u_{0}$ val. A $K$ pont koordinátáit a (21) kifejezésekből kapjuk.

Az OK helyvektor az $x$ tengellyel a

$$
\theta_{0}=\operatorname{arctg} \frac{y\left(u_{0}\right)}{z\left(u_{0}\right)}
$$

szöget zárja. Meg kell jegyezni, hogy a $\theta_{0}$ szög számításakor az arkusz tangensfüggvény értékeit a $[-\pi, \pi]\left\{\frac{-\pi}{2} ; \frac{\pi}{2}\right\}$ intervallumban tekintjük: ha az osztóköri $K$ profilpont a III. illetve a IV. negyedben van, akkor a polárszög negatív, ellenkező esetben pozitív - ez utóbbi a baloldali profilra vonatkozik.

A tetszőleges $M$ profilpontból az $M B$ érintőt húzzuk az alapkörhöz, mely a $K$ ponton áthaladó ideális evolvenst $L$-ben metszi. Az $\mathrm{OM}$ helyvektor polárszögét a (23)-hoz hasonló képlettel számítjuk ki:

$$
\theta_{y}=\operatorname{arctg} \frac{y\left(u_{M}\right)}{z\left(u_{M}\right)}
$$

Az evolvens elméleti lefejtéséből következik, hogy a $K A$ és $L B$ érintő szakaszok hosszának különbsége az $A B$ alapköri ívhossz, melynek a $\angle B O A=\varphi_{y}$ központi szög felel meg. A 4 ábrából leolvasható a szögek közötti alábbi összefüggés:

$$
\varphi_{y}=\arccos \frac{R_{b}^{\prime}}{O M}+\theta_{y}-\left(\theta_{0}+\alpha_{0 t}^{\prime}\right)
$$

Az $\alpha_{y}$ szöget a $B O M$ derékszögü háromszögből számítjuk ki. A (23.. 25) összefüggésekkel a hibát a következőképpen fejezzük ki:

$$
\Delta=R_{b}^{\prime}\left(\operatorname{tg} \alpha_{y}-\operatorname{tg} \alpha_{0 t}^{\prime}-\varphi_{y}\right)
$$

A hiba elöjele az elméleti evolvens csiga és az élek burkoló csigájának relatív helyzetére utal. Ha a hiba pozitív, akkor az evolvens csiga homlokszelvénye a burkoló csiga homlokszelvényén belül esik, aminek következtében a szerszám a szükségesnél több anyagot távolít el a fogárokból, így az elméleti evolvens fogfelületen belül eső felületet alakít ki. Negatív hiba esetében a szerszám hatástérfogata kisebb, így az elméleti evolvens fogfelületet nem takarja ki.

\section{Numerikus kiértékelés}

A modellt $\alpha_{0 n}=20^{\circ}$-os normál lécprofil-szögü, $\quad m_{n}=5 \mathrm{~mm}$ modulú, egyetlen bekezdésű csigamarókra alkalmaztuk. A csigamarók referencia vezércsavarvonaldőlésszögét $\lambda_{01}=2^{\circ}$, illetve $\lambda_{02}=3^{\circ}$-ra választottuk meg. Első esetben a maró fogszáma $z_{m 1}=12$, második esetben pedig $z_{m 2}=10$. A hátramunkálási paraméter értékének kiszámításához $\alpha_{V}=8^{\circ}$-os csúcshátszög-értéket feltételeztünk. Elfogadjuk a szakirodalom ajánlását, miszerint az új csigamarót, az újraélezés következté- 
ben elöálló hibanövekedés megfelezése miatt, a tervezettnél az élezési tartalék felének megfelelő értékkel növelik. Az élezési tartalékot a maró fél fogosztásával tekintik egyenlőnek, így a karakterisztikus sugarak növelése $\frac{1}{2} \frac{\pi}{z_{m}}$ központi szögnek megfelelö Arkhimédész-féle spirális polársugárnövekedésnek, azaz

$$
\frac{1}{2} \frac{\pi}{z_{m}} \frac{k z_{m}}{2 \pi}=\frac{k}{4}
$$

értéknek felel meg. Az új csigamaró éleinek egyenleteit, illetve a burkoló csigát úgy számítjuk ki, hogy a (9) egyenletben az $\varepsilon$ szög értékét $-\frac{\pi}{2 z_{m}}$-nek vesszük.

A hibaszámítást a csigamaró százalékban kifejezett feltételezett kopási állapotára vonatkoztattuk, és négy, a $0,25,75$, illetve 100\%-os kopásnak megfelelő esetet tekintettünk, melyeknek értelemszerüen a következő $\varepsilon$ értékek felelnek meg:

$$
\varepsilon \in\left\{-\frac{\pi}{2 z_{m}} ;-\frac{\pi}{4 z_{m}} ; \frac{\pi}{4 z_{m}} ; \frac{\pi}{2 z_{m}}\right\}
$$

A nulla értéket nem vesszük figyelembe, mert erre az élek evolvens csigát burkolnak, tehát az elméleti profilhiba nulla. A hibák eloszlását az 5-12 ábrák szemléltetik.

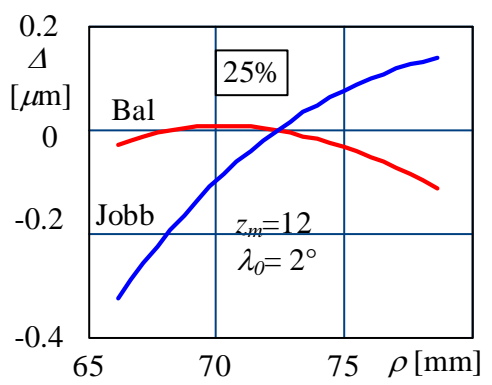

6. ábra. Hibaeloszlás 25\%-ban kopott csigamaró esetében
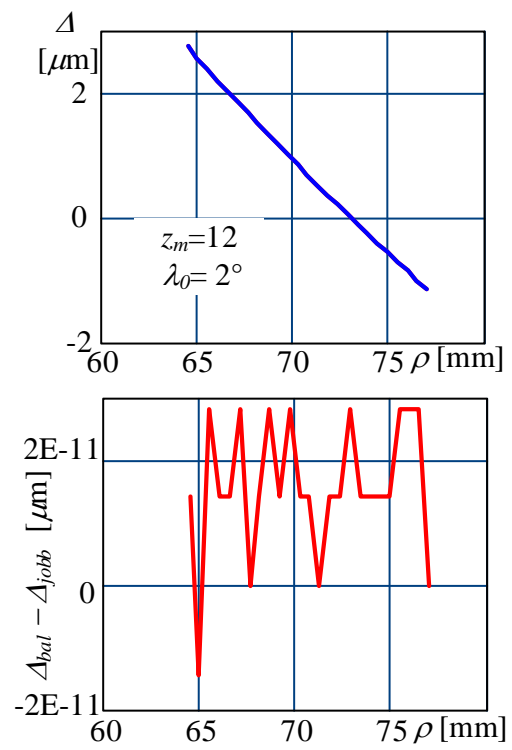

5. ábra. Hibaeloszlás új csigamaró esetében

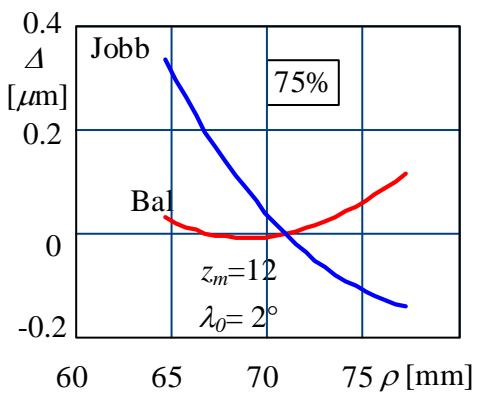

7. ábra. Hibaeloszlás 78\%-ban kopott csigamaró esetében

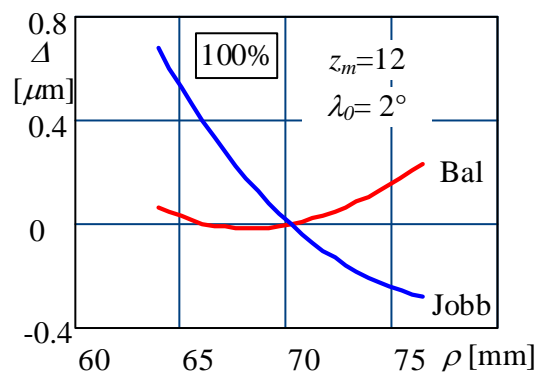

8. ábra. Hibaeloszlás 100\%-ban kopott csigamaró esetében 
Az 5-8 ábrák együttes vizsgálatából megállapítható, hogy a hibáknak az eloszlása mind illeszkedésben, mind pedig értékben összefügg az élezési állapottal, illetve a maró kopásának mértékével. Az új csigamaró élei - érdekes módon - ugyanazt a hibaeloszlást mutatják. Ez derül ki az 5, ábrából, melynek alsó grafikonja a két élen ébredő hiba közötti különbséget mutatja. A különbség nagyságrendje numerikus közelítési hibára utal.

A 6. és 7. ábra két, az ideális élezési állapot ellentétes oldalain elhelyezkedő élezési állapotot, éspedig a 15\%-os, illetve a 75\%-os kopásnak megfelelőt mutatja. Észre lehet venni, hogy a hibafüggvények görbületi iránya megváltozik. A jobb oldali élen jelentősen nagyobb a hiba, mint a bal oldalin, bár ezek értéke elhanyagolható. A hiba elhelyezkedése is ellentétes: 25\%-os kopás esetében a jobb oldali élen az osztóhengersugárnál kisebb sugarak esetében negatív, ezenfelül pozitív, míg a 75\%-os kopás esetében a változás fordított.

A 75\%-os kopástól a teljes kopásig tartó intervallumban a hibák eloszlásfüggvényei megőrzik jellegüket, de az értékek közelítőleg megkétszereződnek.

A 9-12 ábrák a $3^{\circ}$-os vezércsavarvonal- dőlésszögü csigamaróra vonatkoznak. Észre lehet venni, hogy a hibák jelleggörbéi azonosak azokkal, amelyeket a $2^{\circ}$-os vezércsavarvonal- dőlésszögü csigamaróra állítottunk fel.

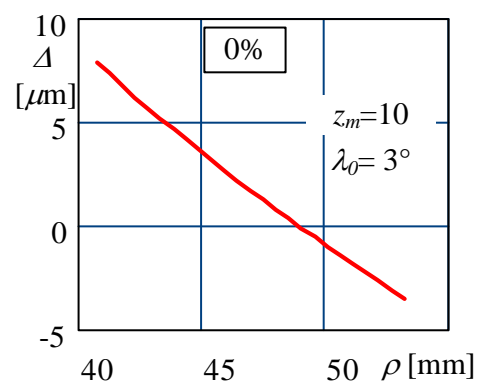

9. ábra. Hibaeloszlás új csigamaró esetében

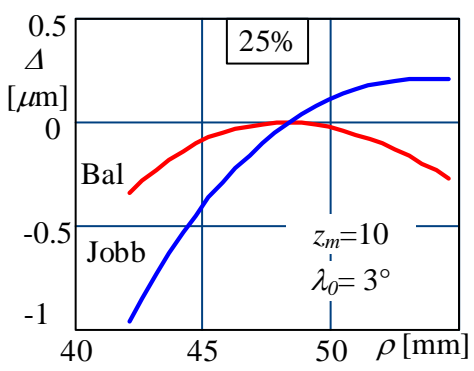

10. ábra. Hibaeloszlás 25\%-ban kopott csigamaró esetében

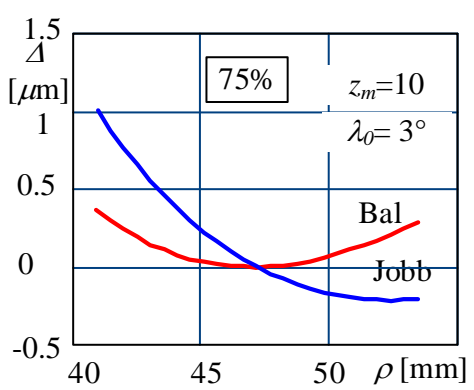

11. ábra. Hibaeloszlás 75\%-ban kopott csigamaró esetében

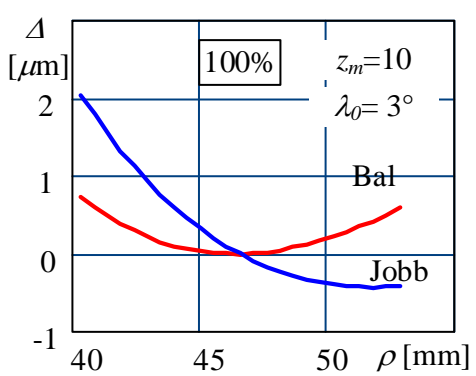

12. ábra. Hibaeloszlás 100\%-ban kopott csigamaró esetében

Az értékek összehasonlító vizsgálata során észre kell vennünk, hogy az új csigamaró esetében a maximális hiba értéke közel $10 \mu \mathrm{m}$, ami megengedhetetlen. Ezzel szemben, a 100\%-ban kopott csigamaró hibaértéke nem nagyobb 3 mikronnál, ami elfogadható. 


\section{Következtetések}

A csigamaró matematikai modelljének numerikus kiértékelése alapján megfogalmazhatóvá válnak a felépítésre és a tervezésre vonatkozó következtetések.

A csigamaró új állapota és a $100 \%$-os mértékben kopott állapota közötti ideális állapot az újraélezési tartalék felénél illeszkedik, ennek ellenére a hibák jóval nagyobbak az ideális állapot elött, mint azt követöen. Ez derül ki a 6-8., illetve a 1012. ábrák összehasonlító vizsgálatából. A 25\%-ra kopott, újraélezett csigamaró hibája közel 6-szor kisebb, $2^{\circ}$-os vezércsavarvonal- dőlésszögü csigamaró esetében, mint az új csigamaróé. A $3^{\circ}$-os csigamaró esetében ez az arány közel 20, ami jelentős!

A 25-75\%-os kopástartományban a hibák, mindkét vizsgált esetben, a mikron körül szóródnak, így ezeknek csupán elméleti jelentőségük van.

A 100\%-os elhasználódású, újraélezett csigamaróknak is elfogadható az állapotnak megfelelő etalon-evolvens csigától való eltérése.

A fenti következtetések alapján elképzelhető, hogy a tervezett ideális csigamaró méreteihez viszonyítva az újraélezési tartalékot nem kell szimmetrikusan elosztani, hanem, a megválasztott csavarvonaldőlésszög függvényében, így eltolni, hogy optimális legyen az eltérés-változás.
Meg kell jegyezni, hogy amennyiben a köszörült hátfelület eltér a jelen tanulmányban elméleti felület-származtatással előállított hátfelülettöl, a torzulás evolúciója változhat.

\section{Szakirodalmi hivatkozások}

[1] Radzevich, P. S.: Dudley's Handbook of Practical Gear Design. CRC-Press, London, 2016, 368-379.

[2] Litvin,F.L.: A fogaskerékkapcsolás elmélete, Müszzaki Könyvkiadó, Budapest, 1972, 187190.

[3] Hollanda, D.: Bazele așchierii și generării suprafețelor, Petru Maior Egyetem, Marosvásárhely, 1994.

[4] Máté, M.: Hengeres fogaskerekek gyártószerszámai, Erdélyi Múzeum-Egyesület, Kolozsvár, 2016, 187-206.

[5] Dudás, I. The Theory and Practice of Gear Worm Drives, Penton Press, London, 2000.

[6] Radzevich, P. S.: Gear Cutting Tools. Fundamentals of design and computation, CRCPress, London, 2010.

[7] Gyenge, Cs.: Lefejtömarók oldalhátszögének pontos meghatározása és optimálása, Gép, 48. évf. (1996), 10 sz, 38-40.

[8] Máté, M. a hengeres fogaskerék-lefejtö csigamaró müködő élgeometriájának vizsgálata. A XVII. Müszaki tudományos ülésszak elöadásai, http://eda.eme.ro/handle/10598/ 29847, ISBN 978-963-449-054-8, 137-147.

[9] Szeniczei, L. Általános fogazás. Nehézipari Müszaki Könyvkiadó, Budapest, 1957. 